\title{
Satellite altimetry over small reservoirs in the Brazilian semiarid region
}

\section{Altimetria por satélite em pequenos reservatórios no semiárido brasileiro}

\author{
Alfredo Ribeiro Neto ${ }^{1}$ (D), Sajedeh Behnia ${ }^{2}$ (D), Mohammad J. Tourian ${ }^{2}$ (D), Fábio Araújo da Costa ${ }^{3}$ (D) $\&$ Nico Sneeuw $^{2}$ \\ ${ }^{1}$ Department of Civil and Environmental Engineering, Universidade Federal de Pernambuco, Recife, PE, Brasil \\ ${ }^{2}$ Institute of Geodesy, University of Stuttgart, Stuttgart, Germany \\ ${ }^{3}$ Serviço Geológico do Brasil, Recife, PE, Brasil \\ E-mails: alfredo.ribeiro@ufpe.br (ARN),sajedeh.behnia@gis.uni-stuttgart.de (SB), tourian@gis.uni-stuttgart.de (MT), \\ fabio.araujo@cprm.gov.br (FAC), nico.sneeuw@gis.uni-stuttgart.de (NS)
}

\begin{abstract}
Northeast Brazil is one of the most populated semiarid regions in the world. The region is highly dependent on reservoirs for human water supply, irrigation, industry, and livestock. The objective of this study was to validate water level time series from the satellites Envisat, SARAL, Sentinel-3A/-3B, Jason-2/-3 in small reservoirs in Northeast Brazil. In total, we evaluated the water level time series of 20 reservoirs. The Sentinel-3B outperforms the other altimeters with a maximum RMSE of $0.21 \mathrm{~m}$. In seven reservoirs with updated depth-area-volume curves, the altimetric water level was used to calculate the corresponding volume. The obtained volume was then compared to the volume given by the same curve by using in situ stage. Our investigations showed that, in the case of small reservoirs, the precision of water level time series derived from satellite altimetry is mainly governed by the seasonal variability of the water storage especially at the end of the 2012-2017 drought period.
\end{abstract}

Keywords: Reservoir monitoring; Remote sensing; Altimetry missions.

\section{RESUMO}

O Nordeste do Brasil é uma das regiões semiáridas mais populosas no mundo. A região é altamente dependente de reservatórios para abastecimento humano de água, irrigação, indústria e pecuária. O objetivo deste estudo foi validar séries temporais de níveis de água dos satélites Envisat, SARAL, Sentinel-3A/-3B, Jason-2/-3 em pequenos reservatórios no Nordeste do Brasil. No total, foram avaliadas as séries temporais de nível da água de 20 reservatórios. O Sentinel-3B superou os outros altímetros com um RMSE máximo de $0,21 \mathrm{~m}$. Em sete reservatórios com curva cota-área-volume atualizadas, o nível de água dos satélites foi utilizado para calcular o volume correspondente. O volume obtido foi então comparado ao volume dado pela mesma curva usando nível medido. Os resultados mostraram que, no caso de pequenos reservatórios, a precisão das séries temporais de nível da água derivadas da altimetria de satélite é governada principalmente pela variabilidade sazonal do armazenamento especialmente no final do período de seca $2012-2017$.

Palavras-chave: Monitoramento de reservatório; Sensoriamento remoto; Missões altimétricas. 


\section{INTRODUCTION}

Reservoirs play a crucial role in the water supply for both urban and rural populations in the semiarid region of Northeast Brazil (NEB). This region is highly dependent on reservoirs to maintain the water supply for people, irrigation, industry, and livestock. Most of the population is supplied by large reservoirs and inter-basin transfer projects such as the São Francisco River Integration Project and the Jaguaribe River Integration Axis in Ceará State (Jonhnsson \& Kemper, 2007). Some studies have shown the role of small and medium-sized reservoirs in the water supply in dispersed communities of the semiarid region in the NEB (Alexandre, 2012; Toledo et al., 2014). These are especially necessary for watersheds where crystalline geology prevails, in contrast to sedimentary geology. The reservoir density in the crystalline geology can be five times greater (Toledo et al., 2014). The main uses of the water are domestic supply, cattle raising, and irrigation for individual families or small, dispersed rural communities (Alexandre, 2012). There are also impacts on hydrological processes in the region. According to results presented by Lima Neto et al. (2011) in the Jaguaribe River Basin $\left(24,600 \mathrm{~km}^{2}\right)$, small and medium-sized reservoirs can retain approximately $50 \%$ of the produced sediment, which means a reduction of impact over the large reservoirs located downstream. On the other hand, the presence of reservoirs in the NEB has disadvantages such as the favoring of the process of evaporation, which can reach around $30 \%$ of the reservoir inflow (de Araújo et al., 2006).

The main objective of measuring water level in reservoirs is to monitor the variations in the storage volume to enable planning and operation of the reservoir. Most medium and large-sized reservoirs in the NEB are monitored, but many of them have long periods of data outages. Satellite radar altimeters were originally designed for ocean observation, whose water height is measured estimating the two-way travel-time of the pulse emitted by the radar (Biancamaria et al., 2017). Details of the principles of altimetry measurement were described in several studies (Kao et al., 2019, Biancamaria et al., 2017; Birkett and Beckley, 2010, among others). With the improvements of radar altimetry, it is growing the number of applications in continental water bodies, including rivers, lakes, reservoirs, and wetlands (Ricko et al., 2012). Satellite altimetry provides a reliable method to fill data gaps of in situ stations and allow the composition of a more consistent and robust water level time series. Moreover, a set of consistent time series can be useful for the validation of other altimetric products as the SWOT (Surface Water and Ocean Topography) mission, foreseen to be launched in February 2022. SWOT has been designed to monitor lakes larger than $250 \times 250 \mathrm{~m}^{2}$ (or $6.25 \mathrm{ha}$ ) (Biancamaria et al., 2016), which constitute $39 \%$ of the reservoirs in the NEB, according to the National Water Bodies Reference Database from the National Water Agency (ANA) (Agência Nacional de Água, 2020). The potential application of SWOT in monitoring small lakes in Sahel, Africa, was shown by Grippa et al. (2019), using a SWOT simulator developed by NASA's Jet Propulsion Laboratory. The lakes tested have a surface area variation between 100 and $250 \mathrm{ha}$. The results achieved an accuracy of $4 \mathrm{~cm}$ and showed the capacity of the SWOT to monitor seasonable variations in the water level (Grippa et al., 2019). This level of accuracy would be a significant contribution to the monitoring of small reservoirs in the NEB. Another contribution of the satellite altimetry in the NEB is the monitoring of small reservoirs not monitored by the governmental agencies. Taking the example of the state of Pernambuco $\left(98,936.79 \mathrm{~km}^{2}\right)$, and based on the National Water Bodies Reference Database, there are 2,702 artificial lakes with surface areas varying between 0.33 ha and 5,426 ha, but just 74 monitored by the state water agency. The information about water availability in the reservoir networks can play an important role in water resources management in the NEB by identifying areas with the worse situation and promoting measures to deal with the risk of scarcity.

Satellite altimetry has shown great potential for application in large rivers and lakes worldwide. Particularly in Brazil, many studies have applied radar altimetry in rivers of the Amazon basin. However, few studies have been developed for small and mediumsized reservoirs. Costa et al. (2016) presented applications in lakes located in Pantanal (Brazil) with areas of $93 \mathrm{~km}^{2}$ and $25 \mathrm{~km}^{2}$ and data retrieval from the satellites Envisat and SARAL. Baup et al. (2014) obtained reliable estimates of water level and volume of water stored in a small lake in France whose surface area is only 52 ha with a storage capacity of $4.1 \mathrm{hm}^{3}$ (average accuracy of $0.12 \mathrm{hm}^{3}$ ). However, the large footprint size of altimeters remains as the main limitation. Despite the improvement brought by the Open-Loop Tracking Command (OLTC) and SAR concept, the spatial resolution is still an obstacle for the application of satellite altimetry in small rivers and reservoirs. Another defining factor over small rivers and lakes is the processing scheme to obtain water level time series. This includes, amongst others, the method by which non-water measurements are excluded, the source for geophysical correction, and the type of retrackers used.

The semiarid region of the NEB has particular characteristics that jeopardize the acquisition of water level from altimetric satellites as, for example, the drastic reduction of water surface during the dry season or during multi-year droughts as occurred between 2012 and 2017.

The assessment of the potential and limitations of the satellite altimetry in the NEB defines the major research question of this study. The objective was, then, to validate water level time series from the satellites Envisat, SARAL, Sentinel-3A/-3B, Jason-2/-3 in small reservoirs in the NEB. In consequence of the validation, secondary objectives were identified: i) volume estimate, and ii) assessment of environmental aspects.

\section{STUDY AREA AND IN SITU DATA}

The NEB covers an area of 1,558 million $\mathrm{km}^{2}$ and has approximately 27,400 reservoirs with a great variety of surface areas, but with a prevalence of small ones (Agência Nacional de Água, 2020). About $98 \%$ of the reservoirs have a surface area lower or equal to $1 \mathrm{~km}^{2}$, which in many cases result in a complete depletion of the water body annually. This characteristic is especially noticeable in long periods of drought. Approximately $57 \%$ of the territory of the NEB is characterized by a semiarid climate and is affected by recurrent droughts because precipitation occurs only in a few months per year, there is strong climate variability, high potential evapotranspiration, geology characterized by crystalline rock, and shallow soil. Most reservoirs of the NEB are located in the semiarid region. 
One group of reservoirs had recently the bathymetry and the depth-area-volume (DAV) curves updated. The topobathymetric survey was executed using an echo sounder for the inundated area and LiDAR technique for the nonwater part. This field work happened within the scope of a set of surveys funded by the ANA in 2017 (Pereira, 2018). The updated DAVs were used in this study to calculate the reservoir storage time series.

The systematic difference between satellite and in-situ water levels was estimated by calculating the average difference of their values. Both time series have the same reference after the subtraction of the systematic difference from the altimetric heights. The selected twenty reservoirs have in situ stations maintained by Water State Agencies and ANA to monitor water level and storage volume. Figure 1 shows the location of the NEB in Brazil and

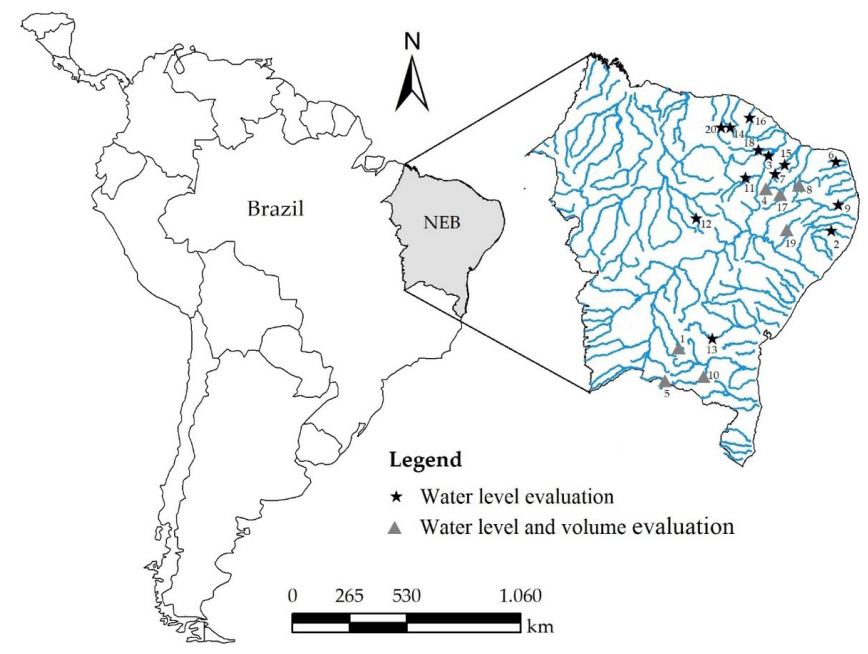

Figure 1. Location of the twenty selected reservoirs. the location of the reservoirs selected. Information about the reservoirs is presented in Table 1. Four reservoirs had more than one mission: Poço da Cruz (Envisat, SARAL and Sentinel-3A), Bandeira de Melo (Jason-2, -3 and Sentinel-3B), Araras (Jason-2, -3 and Sentinel-3A) and Argemiro de Figueiredo (Sentinel-3A and $-3 \mathrm{~B})$. The water level time series have many missing values, which affect the continuous monitoring of the reservoirs. For this reason, in some cases, there were days with the satellite water level recorded, but without in situ data. To minimize this problem, we interpolated the value of the water level when the size of the gap was not greater than 30 days, assuming that the storage variation in the lakes is not abrupt.

\section{MATERIAL AND METHODS}

\section{Water level estimation from satellite altimetry}

Table 2 summarizes the characteristics of the altimetric missions over the selected case studies. Among the missions, SARAL/AltiKa is the only mission operating at Ka-band, offering a higher along-track resolution with respect to the pulse-limited altimeters (e.g. Envisat, Jason-2, and Jason-3). SARAL operated on the long-term Envisat orbit until July 2016 when it was placed on a drifting orbit. Jason-2 and -3 are placed on the long-term TOPEX/Poseidon orbit, equipped with dual-frequency $\mathrm{Ku}$ and C band radar altimeters (Biancamaria et al., 2018). These missions have a higher temporal resolution, but as a consequence, the lowest spatial resolution in terms of inter-track distance. Sentinel-3A and $-3 \mathrm{~B}$ operate in SAR mode with an along-track resolution of 300 $\mathrm{m}$, considered to be the most ideal satellites for monitoring inland waters due to their enhanced spatial resolution (Gao et al., 2019).

Table 1. Set of reservoirs in the study area: WV is the maximum water level variation, E/S for Envisat/SARAL, JA for Jason-2 and -3, S3A for Sentinel-3A, and S3B for Sentinel-3B.

\begin{tabular}{|c|c|c|c|c|c|c|c|c|c|}
\hline & Reservoir & $\begin{array}{c}\text { Area } \\
{\left[\mathrm{km}^{2}\right]}\end{array}$ & $\mathbf{W V}[\mathrm{m}]$ & Lon & Lat & $\mathrm{E} / \mathrm{S}$ & JA & S3A & S3B \\
\hline 1 & Zabumbão & 4.36 & 14.76 & -42.21 & -13.44 & & & $\mathrm{x}$ & \\
\hline 2 & Prata & 4.80 & 12.09 & -35.83 & -8.53 & & & $\mathrm{x}$ & \\
\hline 3 & Poço do Barro & 7.81 & 15.44 & -38.46 & -5.38 & & $\mathrm{x}$ & & \\
\hline 4 & Lagoa do Arroz & 7.81 & 14.52 & -35.57 & -6.80 & & $\mathrm{x}$ & & \\
\hline 5 & Estreito & 8.56 & 10.33 & -42.81 & -14.83 & & & $\mathrm{x}$ & \\
\hline 7 & Pau dos Ferros & 10.97 & 16.64 & -38.19 & -6.15 & & $\mathrm{x}$ & & \\
\hline 8 & Sabugi & 11.83 & 14.16 & -37.20 & -6.65 & $\mathrm{x}$ & & & \\
\hline 9 & Arg. de Figueiredo & 16.95 & 8.82 & -35.56 & -7.44 & & & $\mathrm{x}$ & $\mathrm{x}$ \\
\hline 10 & Anagé & 19.21 & 13.20 & -41.19 & -14.63 & $\mathrm{x}$ & & & \\
\hline 11 & Trussu & 20.45 & 21.83 & -39.43 & -6.31 & $\mathrm{x}$ & & & \\
\hline 12 & Pedra Redonda & 20.56 & - & -41.49 & -8.01 & & & $\mathrm{x}$ & \\
\hline 14 & Edson Queiroz & 25.20 & 15.99 & -40.07 & -4.22 & & & & $\mathrm{x}$ \\
\hline 15 & Santa Cruz do Apodi & 31.95 & 7.11 & -37.80 & -5.76 & & & & $\mathrm{x}$ \\
\hline 16 & Pereira de Miranda & 37.29 & 19.00 & -39.26 & -3.80 & & & & $\mathrm{x}$ \\
\hline 17 & Mãe d’Água & 43.46 & 21.13 & -37.99 & -7.02 & & & $\mathrm{x}$ & \\
\hline 18 & Vinícius Barreto & 47.92 & 15.65 & -38.88 & -5.15 & & & & $\mathrm{x}$ \\
\hline 19 & Poço da Cruz & 54.27 & 23.18 & -37.71 & -8.51 & $\mathrm{x}$ & & $\mathrm{x}$ & \\
\hline 20 & Araras & 67.40 & 20.55 & -40.45 & -4.21 & & $\mathrm{x}$ & $\mathrm{x}$ & \\
\hline
\end{tabular}


Table 2. Specification of altimetric data.

\begin{tabular}{ccccccc}
\hline Mission & Retracker & Period & $\begin{array}{c}\text { Revisit time } \\
{[\text { days }]}\end{array}$ & $\begin{array}{c}\text { Sampling rate } \\
{[\mathbf{H z}] \mid[\mathbf{m}]}\end{array}$ & Source & Version \\
\hline Envisat & ICE-1 & $2002-2010$ & 35 & $18 \mid 400$ & ESA & GDR-V3 \\
SARAL/Altika & ICE-1 & $2013-2016$ & 35 & $40 \mid 175$ & AVISO & GDR-T \\
Jason 2 & ICE-3 & $2008-2017$ & 9.9156 & $20 \mid 350$ & AVISO & PISTACH \\
Jason 3 & ICE-1 & $2016-2019$ & 9.9156 & $20 \mid 350$ & AVISO & GDR-D \\
Sentinel-3A & OCOG & $2016-2019$ & 27 & $20 \mid 300$ & COPERNICUS & O_NT_003 \\
Sentinel-3B & OCOG & $2018-2019$ & 27 & $20 \mid 300$ & COPERNICUS & O_NT_003 \\
\hline
\end{tabular}

These two missions together with Jason-3, benefit from OLTC which has shown to significantly improve data acquisition over inland water bodies (Le Gac et al., 2019).

In order to obtain water level time series, we first define a Virtual Station over each reservoir. VSs were defined based on the static water mask provided by ANA. The water masks are derived based on images of the China-Brazil Earth-Resources Satellite (CBERS), Landsat, and RapidEye (Agência Nacional de Água, 2020).

Within the defined VS, altimetric water level is initially determined for each sample. To this end, first, range measurements from the selected retrackers (Table 2) are corrected for geophysical effects (solid earth tide and pole tide) and path delays caused by the atmosphere (wet tropospheric, dry tropospheric, and ionospheric). Our choice of retrackers of different missions is based on their performance over inland waters (da Silva et al., 2010). The corrected range is then subtracted from the satellite altitude to obtain the water level for each sample. In the next step, the reference height is changed to geoid according to static gravity field model XGM2019e (Pail et al., 2018). At each overpass, the median of the obtained orthometric heights from all samples inside the VS is chosen to be the representative height. Despite the robustness of the median estimates, the resulting water level time series may still be contaminated by outliers. To identify the outliers, we use an iterative data-driven outlier identification method, which relies on the temporal behavior of water level time series.

\section{Water level and volume assessment}

The quality of the satellite data relative to in situ measurements was assessed using the root mean square error (RMSE). After the assessment of the satellite stage data, we calculated the volume in the seven reservoirs with DAV curves established by the bathymetric survey (highlighted in Figure 1). The water level measured by the satellites was used in the DAV curves to calculate the corresponding volume, and then, compared to the volume given by the same curves, using in situ stage. The quality of the estimated volume was assessed with the relative root mean square error (RRMSE), given by the ratio between RMSE of the volume and the mean measured volume. Besides, the error in volume was calculated using the expression

$\Delta V(\%)=\frac{V_{\text {satellite }}-V_{\text {in situ }}}{V_{\text {in situ }}} \cdot 100$

where $\mathrm{V}_{\text {satellite }}$ is the volume estimated with satellite water level and $\mathrm{V}_{\text {in situ }}$ is the measured volume.

\section{RESULTS AND DISCUSSION}

The next sections present the performance of the altimetry missions and the results concerning lakes influenced by environmental aspects.

\section{Water level time series}

The processed data had a variety of results in terms of the behavior of the water surface detected by the satellites, e.g., satisfactory retrieval, non-processed cycles, and values out of the pattern (i.e., excessively high, or low).

All selected reservoirs had a water level variation greater than seven meters according to in situ time series. The satellite data followed satisfactorily the seasonality of the stages in the lake. Table 3 summarizes the RMSE obtained in the reservoirs and the

Table 3. RMSE, number of samples (n) (processed cycles), and non-processed cycles (npc) for each mission and reservoir.

\begin{tabular}{|c|c|c|c|c|}
\hline Mission & Reservoir & RMSE (m) & $n$ & npc \\
\hline \multirow{4}{*}{ Envisat } & Poço da Cruz & 0.30 & 50 & 0 \\
\hline & Sabugi & 0.28 & 79 & 3 \\
\hline & Anagé & 0.40 & 72 & 11 \\
\hline & Trussu & 0.28 & 42 & 2 \\
\hline \multirow{4}{*}{ SARAL } & Poço da Cruz & 0.40 & 12 & 6 \\
\hline & Sabugi & 0.17 & 14 & 9 \\
\hline & Anagé & 0.17 & 24 & 6 \\
\hline & Trussu & 0.35 & 15 & 3 \\
\hline \multirow{5}{*}{ Jason 2} & Lagoa do Arroz & 0.27 & 142 & 53 \\
\hline & Bandeira de Melo & 0.29 & 99 & 38 \\
\hline & Pau dos Ferros & 0.21 & 245 & 53 \\
\hline & Poço do Barro & 0,86 & 177 & 22 \\
\hline & Araras & 0.32 & 298 & 3 \\
\hline \multirow{5}{*}{ Jason 3} & Lagoa do Arroz & 0.39 & 55 & 41 \\
\hline & Bandeira de Melo & 0.35 & 71 & 32 \\
\hline & Pau dos Ferros & 0.19 & 44 & 78 \\
\hline & Poço do Barro & 0.84 & 89 & 7 \\
\hline & Araras & 0.14 & 86 & 38 \\
\hline \multirow{6}{*}{ Sentinel-3A } & Poço da Cruz & 0.76 & 15 & 10 \\
\hline & Mãe d'Água & 0.20 & 38 & 14 \\
\hline & Estreito & 0.50 & 41 & 7 \\
\hline & Zabumbão & 1.01 & 33 & 5 \\
\hline & Prata & 0.81 & 22 & 27 \\
\hline & Araras & 0.97 & 37 & 15 \\
\hline \multirow{4}{*}{ Sentinel-3B } & Bandeira de Melo & 0,13 & 12 & 2 \\
\hline & Argemiro de Figueiredo & 0.06 & 14 & 0 \\
\hline & Edson Queiroz & 0.21 & 15 & 0 \\
\hline & Vinícius Barreto & 0.11 & 11 & 4 \\
\hline
\end{tabular}


number of non-processed cycles (npc). We considered an npc when the processing returned $\mathrm{NaN}$ or outlier values. There were five cases where the number of npc became the RMSE calculation nonviable and, for this reason, these cases were not considered as successful processing (not shown in Table 3). Figure 2 presents the time series of four reservoirs (Poço da Cruz, Lagoa do Arroz, Sabugi, and Mãe d'Água), which allows illustrating the behavior of the water level. The RMSE obtained was investigated together with other parameters including maximum surface area, maximum storage capacity, maximum and minimum width of the water body along the tracks, number of samples, and number of days. However, no clear relationship between the obtained RMSE and any of these parameters was found except for the Sentinel-3A in which the maximum surface area affected the results.

Figure 3 presents the DAV curves available for the reservoirs analyzed. Figure 4 shows the variation of the storage volume in four reservoirs using the satellite data as input into the DAV curve, as well as the volume calculated with the in situ stages. Both types of volume agreed well, and the average error did not exceed $2.36 \%$ as shown in Table 4.
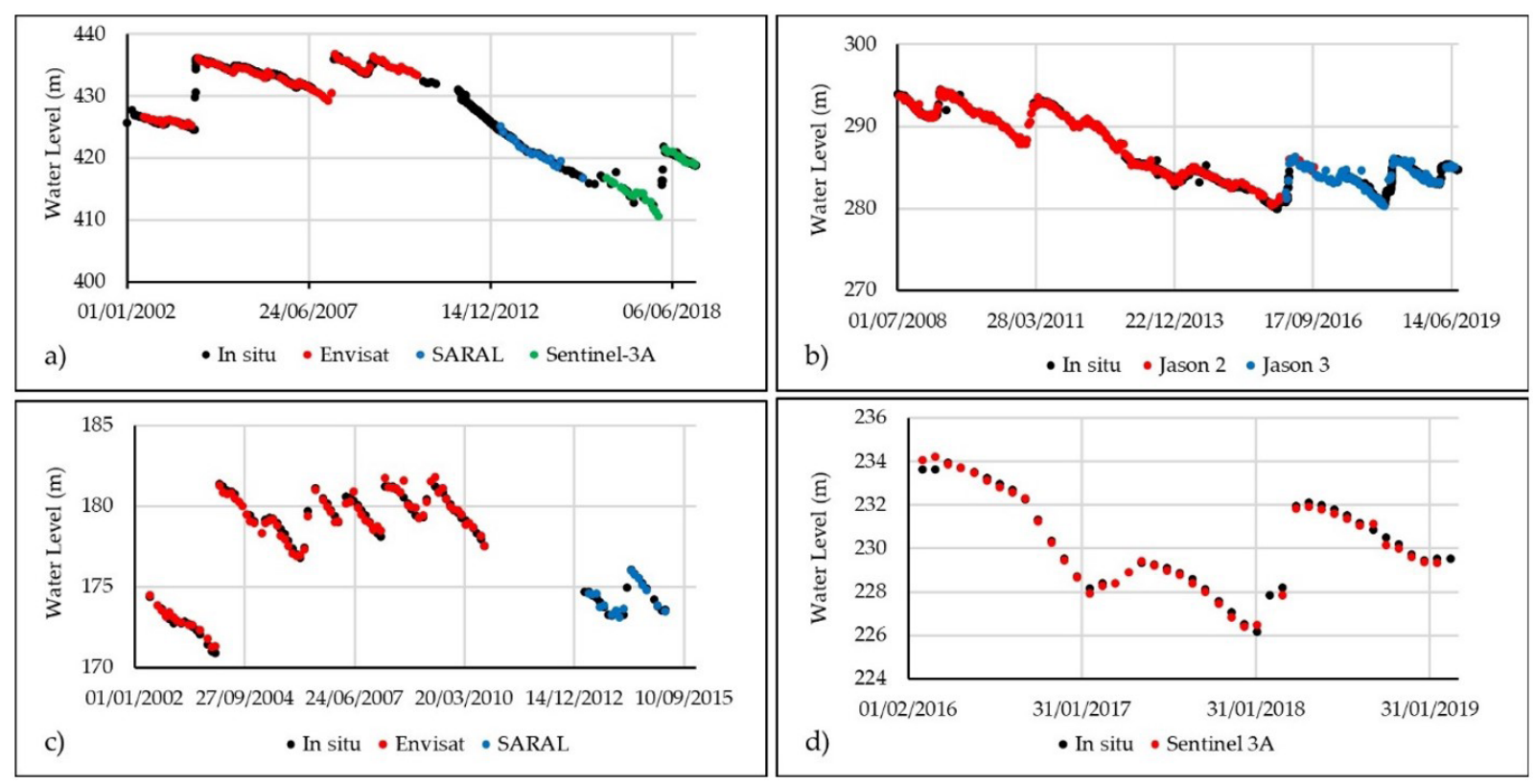

Figure 2. Water level time series in Poço da Cruz (a), Lagoa do Arroz (b), Sabugi (c) and Mãe d’Água (d) reservoirs.

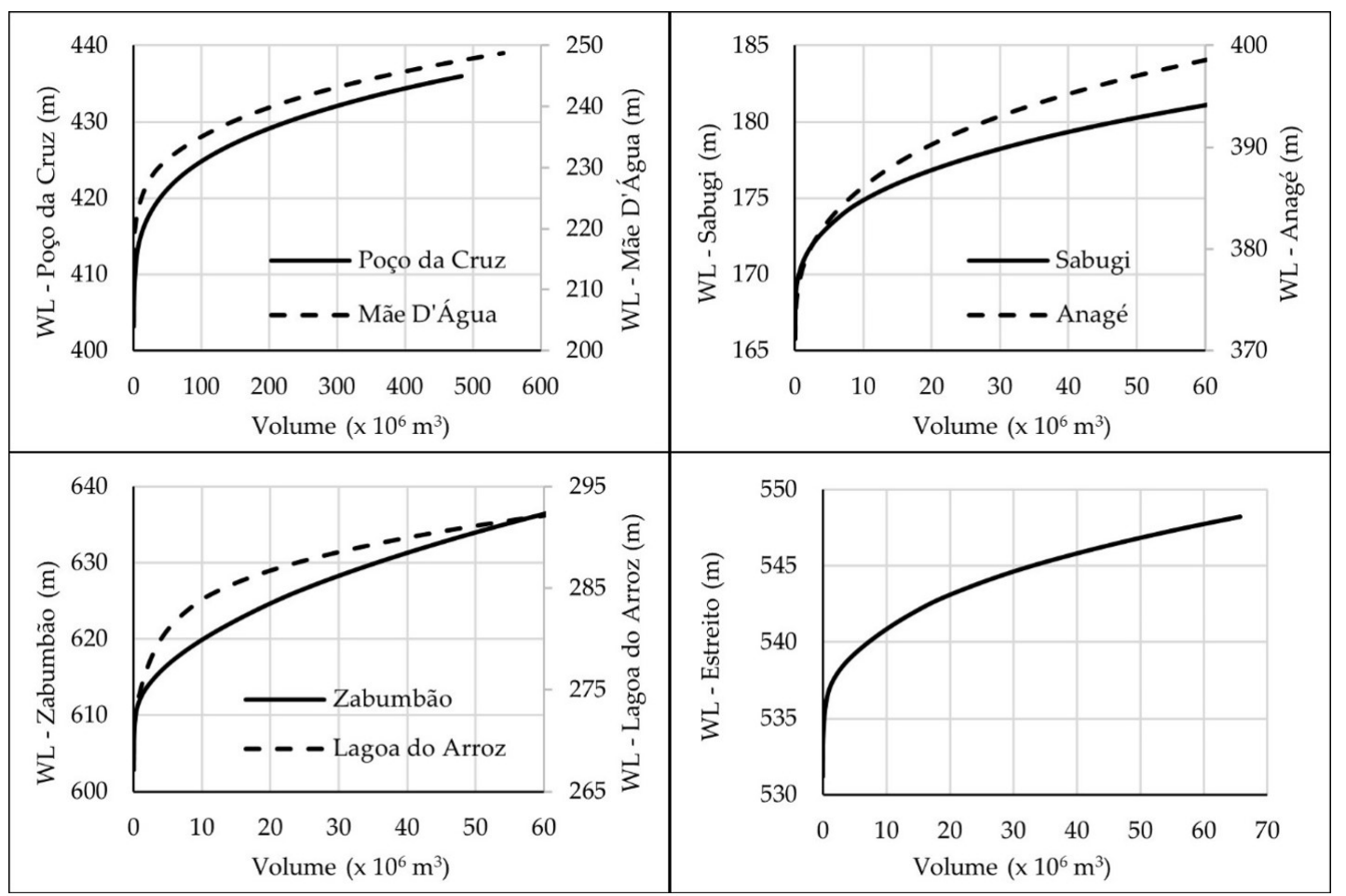

Figure 3. DAV curves available in seven reservoirs (Y-axis represents water level - WL). 

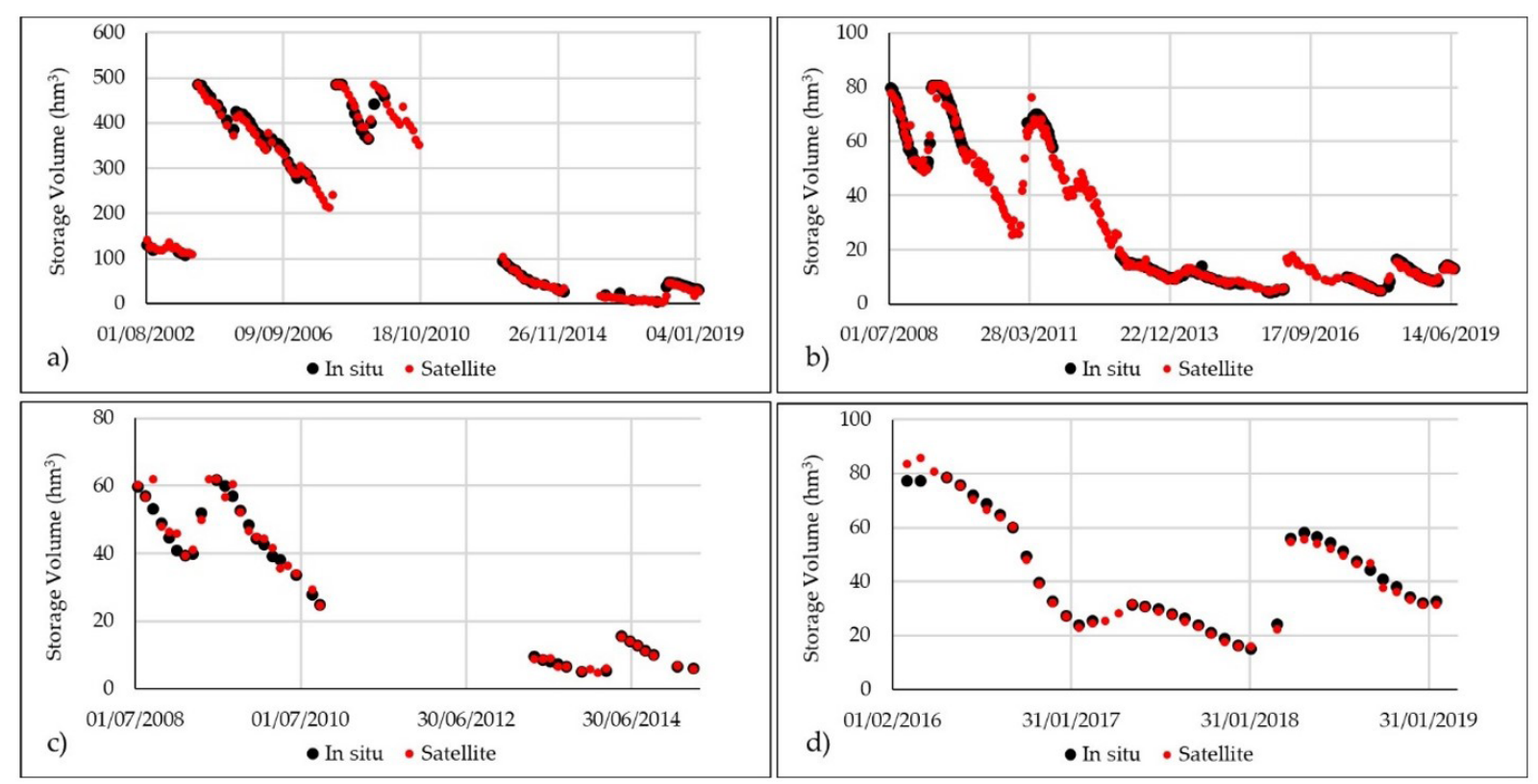

Figure 4. Storage volume in Poço da Cruz (a), Lagoa do Arroz (b), Sabugi (c) and Mãe d’Água (d) reservoirs.

Table 4. The error of the volume calculated with water level from the satellite.

\begin{tabular}{ccccc}
\hline Reservoir & $\begin{array}{c}\text { Capacity } \\
\left(\mathbf{( h m}^{\mathbf{3}}\right)\end{array}$ & $\begin{array}{c}\mathbf{R M S E} \\
\mathbf{( h m}^{\mathbf{3}} \mathbf{)}\end{array}$ & $\begin{array}{c}\mathbf{R R M S E} \\
\mathbf{( \% )}\end{array}$ & $\boldsymbol{\Delta V} \mathbf{( \% )}$ \\
\hline Poço da & 483.72 & 9.28 & 3.94 & -1.34 \\
Cruz & & & 6.93 & -1.10 \\
Sabugi & 61.82 & 2.21 & 2.80 & -0.22 \\
Anagé & 229.09 & 5.25 & 5.13 & -1.05 \\
Mãe d’Água & 545.02 & 2.17 & 15.73 & 2.36 \\
Estreito & 65.71 & 3.08 & 11.46 & 1.13 \\
$\begin{array}{c}\text { Zabumbão } \\
\text { Lagoa do } \\
\text { Arroz }\end{array}$ & 61.34 & 2.50 & 5.22 & -0.70 \\
\hline
\end{tabular}

\section{Assessment of environmental aspects}

The results from five reservoirs did not allow the RMSE calculation: Pedra Redonda (Sentinel-3A), Pereira de Miranda (Sentinel-3B), Argemiro de Figueiredo (Sentinel-3A), Santa Cruz do Apodi (Sentinel-3B), and Poço Branco (Sentinel-3B). We investigated three possible reasons for the quality of data retrieval obtained in these reservoirs: seasonal variability, branches with very small widths, and topographic characteristics near the shore. One recurrent problem that occurs in the NEB is the high seasonal variability of the storage in the reservoirs. This is particularly severe in multi-year droughts when there is lingering annual precipitation below the long-term average as occurred in the recent period 2012-2017. In some cases, the tracks did not cross the main course of the lake, but small tributaries or the river at the entrance of the lake (see Figure 5).

The Pedra Redonda reservoir can be classified as a narrow reservoir (Figure 5); the ground track of the Sentinel-3A crosses it in the entrance far from the main body. Another problem identified was the impact caused by falling water levels due to sustained drought. This was the case of the Pau dos Ferros reservoir, where the Jason-2 measured satisfactorily water level until July 2015. Images before and after this date (Figure 6) illustrate the influence of the drought on the quality of the data. A combination of these two cases (small width and falling water level) can explain the unsatisfactory processing data obtained in Pereira de Miranda (Sentinel-3B) and Argemiro de Figueiredo (Sentinel-3A). In both cases, besides the influence of the falling water level, the ground tracks cross the reservoirs in a branch away from the main body of the lake.

The surrounding topography also influenced the altimetric results of two reservoirs for the Sentinel-3B data. The profiles along the tracks were extracted from the Digital Terrain Model (DTM) of the Shuttle Radar Topography Mission, with a $30 \mathrm{~m}$ spatial resolution, provided by the Earth Explorer US Geological Survey. The difference of altitude between the water and the hill near the Santa Cruz do Apodi reservoir (Figure 7a) is $50 \mathrm{~m}$ with a corresponding slope of $60 \mathrm{~m} \cdot \mathrm{km}^{-1}$. In the Poço Branco reservoir (shown in Figure 7b), the difference of altitude is $28 \mathrm{~m}$ and a slope of $14 \mathrm{~m} \cdot \mathrm{km}^{-1}$, admitting the water level on the lowest part of the DTM.

\section{Discussion}

The research presented in the literature supports the discussion of the results obtained for the NEB. Table 5 shows the RMSE values found in applications in several water bodies worldwide using altimetric data from the same satellites used in the NEB study.

Envisat

The result obtained in the present application was similar to Baup et al. (2014), who found an RSME value of 27 $\mathrm{cm}$ with Envisat data (in the NEB the values varied between 


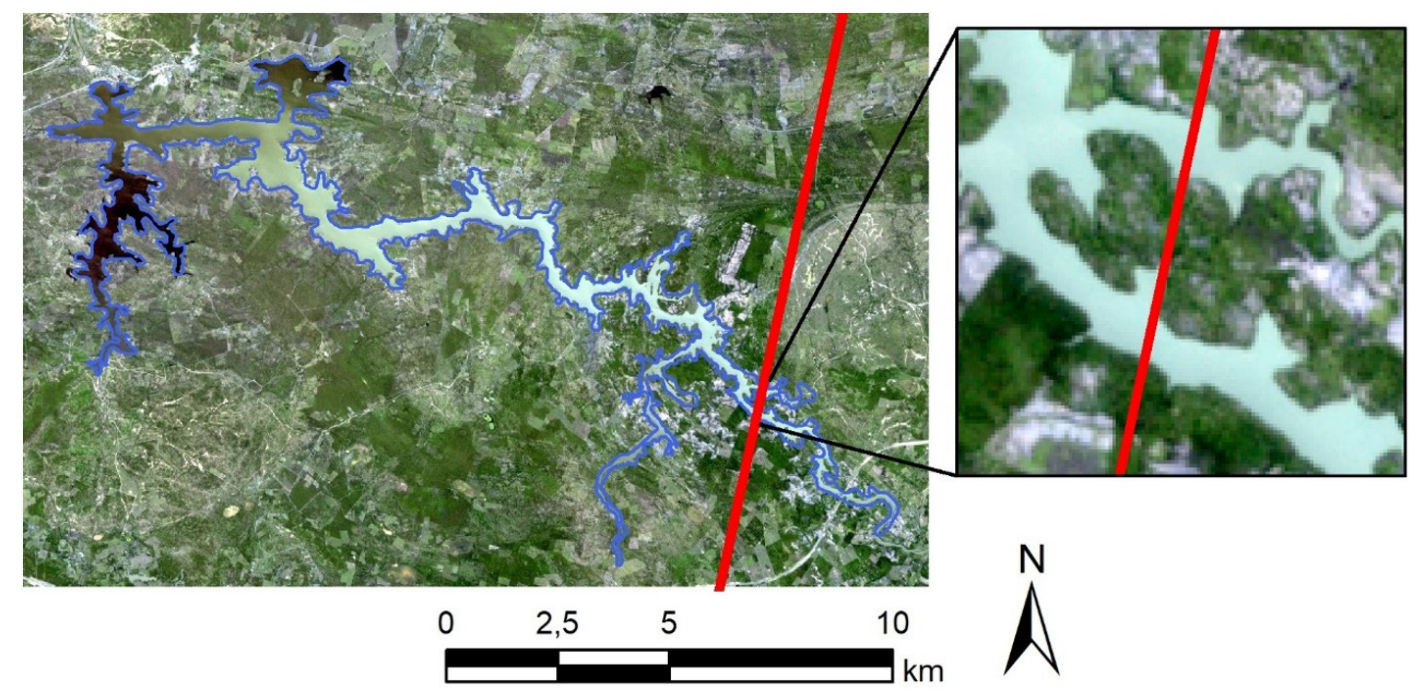

Figure 5. Ground track of the Sentinel-3A over small width at Pedra Redonda reservoir (Piauí state).
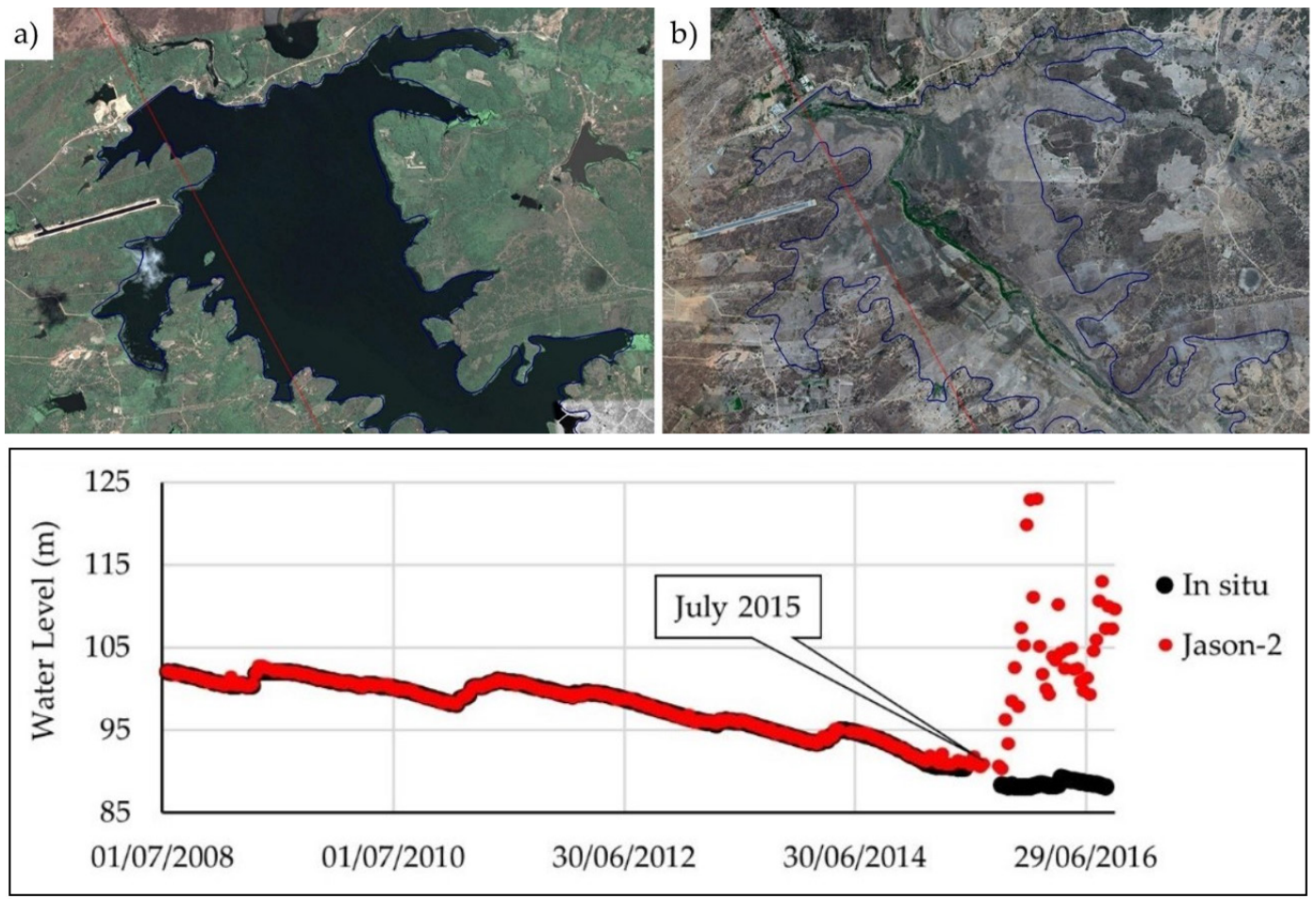

Figure 6. Pau dos Ferros reservoir (Rio Grande do Norte state) affected by long drought periods: storage in October 2012 (a) and April 2016 (b).

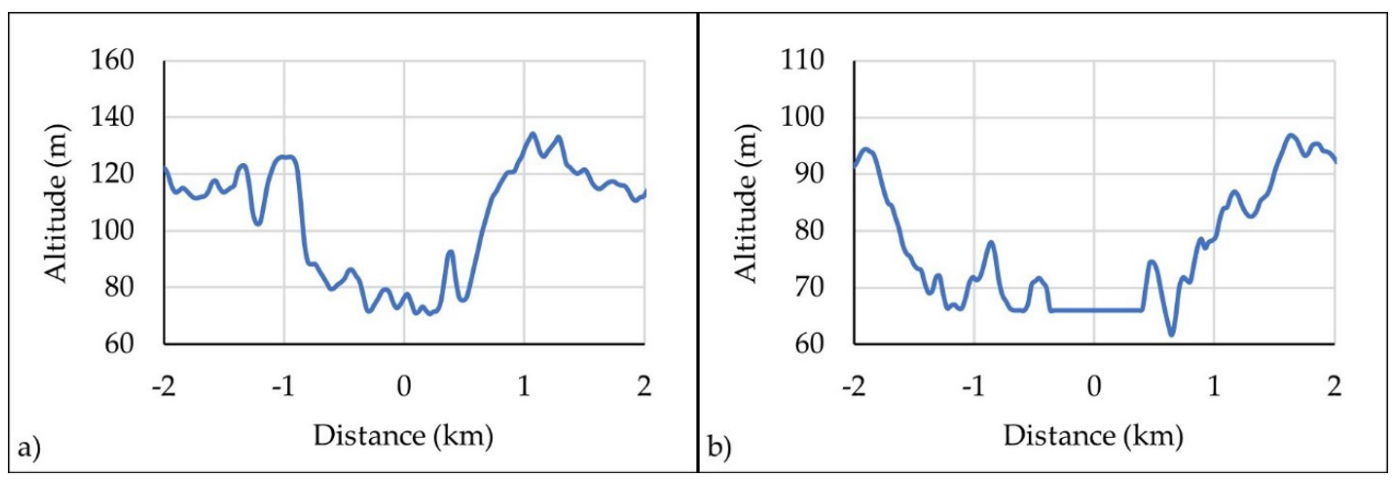

Figure 7. Cross-section profile of reservoirs influenced by surrounding topography: Santa Cruz do Apodi (a) and Poço Branco (b). 
Table 5. Summary of results in other water bodies.

\begin{tabular}{|c|c|c|c|c|c|}
\hline \multirow{2}{*}{ Mission } & \multirow{2}{*}{ Reference } & \multicolumn{2}{|c|}{ RMSE [m] } & \multirow{2}{*}{ Hydro-object } & \multirow{2}{*}{ Characteristic } \\
\hline & & Study & NEB & & \\
\hline \multirow{4}{*}{ Envisat } & Baup et al. (2014) & 0.27 & \multirow{4}{*}{$0.28-0.40$} & Reservoir & 52 ha \\
\hline & da Silva et al. (2010) & $0.118-0.81$ & & Amazon & Width $<500 \mathrm{~m}$ \\
\hline & Sulistioadi et al. (2015) & $0.21-0.69$ & & Rivers and lakes & 40-200 m wide \\
\hline & Michailovsky et al. (2012) & $0.24-1.06$ & & River & $40-400 \mathrm{~m}$ wide \\
\hline \multirow{4}{*}{ SARAL } & Kao et al. (2019) & $0.11 ; 0.16$ & \multirow{4}{*}{$0.17 ; 0.40$} & Two lakes & Tibetan Plateau \\
\hline & Schwatke et al. (2015) & $0.078-0.318$ & & Amazon & $2.3-17.5 \mathrm{~km}$ wide \\
\hline & Chander \& Ganguly (2017) & 0.12 & & Reservoir & $520 \mathrm{~km}^{2}$ \\
\hline & Arsen et al. (2015) & $0.05-1.18$ & & Lakes in the Andes & $0.7-28.7 \mathrm{~km}$ wide \\
\hline \multirow{2}{*}{ Sentinel-3A } & Jiang et al. (2020) & $<0.60$ & \multirow{2}{*}{$0.20-1.01$} & Rivers & Width < $400 \mathrm{~m}$ \\
\hline & Gao et al. (2019) & $0.20 ; 1.39$ & & Rivers and lakes & $400 \mathrm{~m} ; 130 \mathrm{~m}$ wide \\
\hline \multirow{3}{*}{ Jason-2/-3 } & Birkett \& Beckley (2010) & $0.03-0.33$ & \multirow{3}{*}{$0.27-0.80$} & Lakes & $\sim 800$ m wide \\
\hline & Ricko et al. (2012) & $0.05-1.41$ & & Lakes & $>100 \mathrm{~km}^{2}$ \\
\hline & Jarihani et al. (2013) & 0.28 & & Lake & $\sim 1000 \mathrm{~m}$ wide \\
\hline
\end{tabular}

$28 \mathrm{~cm}$ and $40 \mathrm{~cm}$ for the lakes analyzed). da Silva et al. (2010) evaluated the Envisat altimetric data in several rivers in the Amazon basin with a large variety of widths. The rivers with a width lower than $500 \mathrm{~m}$ (a total of 12 rivers) had RMSE varying between $11.8 \mathrm{~cm}$ and $81 \mathrm{~cm}$ (from this total six rivers had RMSE lower than $30 \mathrm{~cm}$ ). The application of Envisat data to small water bodies was also attempted by Sulistioadi et al. (2015) in Indonesia. They selected the waveforms that minimize non-water signal contamination in small (40-200 m wide) and medium-sized (200-800 m) rivers and lakes. Even without waveform selection, the results obtained in the NEB with Envisat were similar to those calculated by Sulistioadi et al. (2015) (RMSE of 21-69 cm). The lakes in the NEB were processed using masks as carried out by Michailovsky et al. (2012) in the Zambezi River, where the width varied between 40 and $400 \mathrm{~m}$ and the RMSE was $24-106 \mathrm{~cm}$.

\section{SARAL}

An application of SARAL in two lakes of the Tibetan Plateau presented an RMSE of 11 and $16 \mathrm{~cm}$ (Kao et al., 2019), a performance better than the Cryosat-2 also over the same lakes, which demonstrates, according to the authors, the superiority of the Ka-band over the Ku-band. The RMSE obtained by Schwatke et al. (2015) varied between 7.8 and $31.8 \mathrm{~cm}$ in the Amazon basin with a range of river widths from $2.3 \mathrm{~km}$ to 17.5 $\mathrm{km}$. The values found in the NEB varied between $17 \mathrm{~cm}$ (Sabugi) and $40 \mathrm{~cm}$ (Poço da Cruz). The former can be considered close to that obtained in other studies, despite the reduced surface area of the Sabugi reservoir. For example, the assessment carried out by Chander \& Ganguly (2017) at the Ukai reservoir (surface area of $520 \mathrm{~km}^{2}$ ) in India had errors of $12 \mathrm{~cm}$ using the ICE-2 retracker. Arsen et al. (2015) assessed Envisat and SARAL in mountainous lakes in the Andean cordillera in South America. For lakes with a width greater than $3 \mathrm{~km}$, the accuracy of SARAL varied between 5 and $31 \mathrm{~cm}$, significantly better than Envisat ( 9 to $359 \mathrm{~cm}$ ). On the other hand, for cross-sections lower than $3 \mathrm{~km}$, the time series for both satellites were not exploitable.
Sentinel-3A and -3B

As the Sentinel missions are more recent, fewer cycles were included in the analysis. The four lakes with Sentinel-3A data processed had RMSE varying from 20 to $101 \mathrm{~cm}$. There was a relation between the size of the lakes and the value of the RMSE, i.e., the lowest RMSE value for the second biggest area and the greatest RMSE value for the smallest lake. Jiang et al. (2020) did not find a direct relation between RMSE values and river width in China. Some rivers with cross-sections lower than $400 \mathrm{~m}$ had RMSE $<60 \mathrm{~cm}$, whilst others with a width greater than $1000 \mathrm{~m}$ had RMSE $>2.0 \mathrm{~m}$. Gao et al. (2019) processed Sentinel-3A data for rivers and lakes in the Ebro River basin in Spain. Among the water bodies processed, two small lakes presented distinct results depending on the width: RMSE of $20 \mathrm{~cm}$ for a $400 \mathrm{~m}$ wide lake and $1.39 \mathrm{~m}$ for another $130 \mathrm{~m}$ wide lake. In the NEB, the Sentinel$3 \mathrm{~B}$ outperforms the other altimeters with a maximum RMSE of $0.21 \mathrm{~m}$. Due to the small number of samples, it is recommended to process extended data from Sentinel-3B to confirm the results. Besides, note the existence of some advantages of the reservoirs with Sentinel-3B data. The maximum surface area of the reservoirs varies between 16.95 and $47.92 \mathrm{~km}^{2}$ (not so small), the positions of the ground tracks crossing the reservoirs are favorable and the time series started after the 2012-2017 drought period. The opposite may have occurred in the reservoirs with Sentinel-3A data. Two out of six reservoirs have a maximum surface area lower than 5 $\mathrm{km}^{2}$ (Zabumbão and Prata), the ground track passes in branches of the reservoir (Araras), and the 2012-2017 drought can have affected its performance (Figure $2 \mathrm{a}$ shows the low water level in the Poço da Cruz reservoir).

\section{Jason-2 and -3}

Applications carried out by Birkett \& Beckley (2010) using Jason-2 data in 28 lakes worldwide showed variations of RMSE between 3 and $33 \mathrm{~cm}$. Data from TOPEX/POSEIDON and Jason-1 and -2 were validated with in situ data from 18 lakes for the period 1992-2011 and RMSE varying from 87 to $99 \mathrm{~cm}$ (Ricko et al., 2012). In the lake Argyle Eildon (Australia), the Jason-2 data had 
an RMSE of $28 \mathrm{~cm}$ (Jarihani et al., 2013). Jason-2 and -3 in the NEB reached a similar performance (RMSE between 27 and 45 $\mathrm{cm})$, except for Poço do Barro lake whose error was greater than $80 \mathrm{~cm}$. In a comparison of rivers in France with Jason-2 and -3 data, Biancamaria et al. (2018) found satisfactory results, even in narrow rivers (e.g., $40 \mathrm{~m}$ wide). In this French study, owing to an alternative operation mode, Jason-3 dealt better with impacts caused by the surrounding topography.

\section{Volume estimate and environmental aspects}

The volume calculated in five of the seven reservoirs that have updated DAV curves had a similar performance to Baup et al. (2014), taking RRMSE as the assessment criterion. Baup et al. (2014) found 5\% for RRMSE and the values found in the seven reservoirs varied between $2.80 \%$ and $15.73 \%$ (Table 4 ). There was a trend of the volume calculated with satellite data to underestimate the volume calculated using the in situ water level (five out of seven reservoirs); despite this, the error of volume $(\Delta \mathrm{V}$ in Table 4$)$ can be considered satisfactory.

The altimetric data from some of the reservoirs failed to deliver useful water levels. This problem also occurred in the application of satellite altimetry in mountainous regions with SARAL data (Arsen et al., 2015) and Sentinel-3A (Jiang et al., 2020). Biancamaria et al. (2017) investigated the influence of the topography on the quality of the water level estimated by Envisat, SARAL, and Jason-2 in the Garonne River in France. They showed that, in rivers surrounded by hilly areas, the altimeter tends to observe the hills instead of the water and gave some examples to illustrate this influence. When the track crosses a smoother terrain, there is more time for the closed-loop tracking algorithm to adapt to the hills/valley transition, which is different from a situation where the transition is almost perpendicular to the valley (Biancamaria et al., 2017). Analyses carried out over French rivers (Biancamaria et al., 2017,2018 ) suggest that the performance of the altimeter is adversely affected in steep-sided valleys with a height of 50-100 $\mathrm{m}$ or a slope of $80 \mathrm{~m} \cdot \mathrm{km}^{-1}$. The results obtained in the lakes of the NEB were evaluated considering these two values as a base of comparison. The difference of altitude between the water and the hilltop near the lake and the slope of the terrain in the path of the ground track could explain the problems that occurred in two cases. Two reservoirs in the NEB with a failure in the retracking had similar characteristics (difference of altitude of $50 \mathrm{~m}$ and 28 m). Maillard et al. (2015) investigated the relationship between the quality of the results obtained with Envisat and SARAL in the São Francisco River (Brazil) and environmental factors as land cover along the satellite track and river morphology. The authors, for example, identified problems in the processing of the SARAL data related to narrow river stretches where the water surface was detected, but the signal referred to off-nadir returned.

Environmental characteristics could have affected the performance of some satellites in this study. The impacts of the seasonal and interannual water level variability were amplified in the 2012-2017 drought period, which coincided partially with the time series of SARAL, Jason 3, and Sentinel-3A. Despite this drawback, the accuracy of SARAL was equivalent to Envisat. A reduction of the effects caused by the falling water in the reservoirs could be attributed to the Ka-band altimeter of the SARAL mission. The same explanation can be invoked to discuss the performance obtained by Jason-3 and Envisat-3A, but in these cases, the OLTC would be the mission characteristic that attenuated the impacts of low water level. As argued previously, ground track location can also have contributed to the Sentinel-3A results.

\section{CONCLUSIONS}

The application of satellite altimetric data in reservoirs of the NEB demonstrated the great potential of this tool for water level monitoring in this region. The results can be considered equivalent to those obtained in small rivers and reservoirs from other regions around the world. It is important to mention that the number of reservoirs analyzed was not large enough to conclude about the difference of performance in general terms among the missions. The results obtained in this analysis also showed the potential of the application of altimetric missions projected for the future. The temporal resolution is not necessarily the biggest problem, considering the variation of storage water in the reservoirs is compatible with the revisiting time of the missions already in operation. The main contribution of the new missions would be the improvement of the capacity to detect not only more lakes but also smaller ones. Even the lakes already monitored with in situ stations can benefit. As verified in this research, the time series information from many reservoirs has problems with missing data. Unlike streamflow data in rivers, it is not possible to fill gaps concerning long periods of water level and volume data of reservoirs. Satellite altimetry can be useful to fill these gaps in the level and volume time series of reservoirs in the NEB.

Owing to the influence of environmental characteristics of the region, the processing routine failed to derive accurate results. For this reason, it is important to apply an efficient method for outlier rejection. The water level amplitude, i.e. the variation of the minimum and maximum stages, in the water bodies of the NEB is an important aspect that must be considered in an analysis of satellite altimetry in this region. Due to the strong seasonal and interannual variability, the effective width decreases significantly, mainly in the branches away from the main course of the reservoirs. Considering the similarity of the hydrological processes, similar problems can be found in other semiarid regions like the NEB. In the next satellite altimetry applications in the NEB, it is important to assess how the choice of the retracker can improve the performance of the altimeters, considering the particular characteristics of the region.

\section{ACKNOWLEDGEMENTS}

This work was supported by the Coordenação de Aperfeiçoamento de Pessoal de Nível Superior - Brazil (CAPES) under grant 88887.466424/2019-00 (a Foreign Visiting Professor scholarship for the first author).

\section{REFERENCES}

Agência Nacional de Água - ANA. (2020). Atualização da Base de Dados Nacional de Referência de Massas d'Água $(27$ p., Nota técnica 
$\mathrm{n}^{\mathrm{o}}$ 52/2020/SPR. Documento No. 02500.025402/2020-63). Brasília: ANA.

Alexandre, D. M. B. (2012). Gestão de pequenos sistemas hidricos no semiárido nordestino (Tese de doutorado). Universidade Federal do Ceará, Fortaleza.

Arsen, A., Cretaux, J. F., \& Del Rio, R. A. (2015). Use of SARAL/ AltiKa over Mountainous Lakes, Intercomparison with Envisat Mission. Marine Geodesy, 38, 534-548. http://dx.doi.org/10.1080 /01490419.2014.1002590.

Baup, F., Frappart, F., \& Maubant, J. (2014). Combining highresolution satellite images and altimetry to estimate the volume of small lakes. Hydrology and Earth System Sciences, 18, 2007-2020.

Biancamaria, S., Frappart, F., Leleu, A. S., Marieu, V., Blumstein, D., Desjonqueres, J. D., Boy, F., Sottolichio, A., \& Valle-Levinson, A. (2017). Satellite radar altimetry water elevations performance over a $200 \mathrm{~m}$ wide river: Evaluation over the Garonne River. Advances in Space Research, 59, 128-146. http://dx.doi.org/10.1016/j. asr.2016.10.008.

Biancamaria, S., Lettenmaier, D. P., \& Pavelsky, T. M. (2016). The SWOT Mission and Its Capabilities for Land Hydrology. Surveys in Geophysics, 37, 307-337. http://dx.doi.org/10.1007/ s10712-015-9346-y.

Biancamaria, S., Schaedele, T., Blumstein, D., Frappart, F., Boy, F., Desjonqueres, J. D., Pottier, C., Blarel, F., \& Nino, F. (2018). Validation of Jason-3 tracking modes over French rivers. Remote Sensing of Environment, 209, 77-89. http://dx.doi.org/10.1016/j. rse.2018.02.037.

Birkett, C. M., \& Beckley, B. (2010). Investigating the Performance of the Jason-2/OSTM Radar Altimeter over Lakes and Reservoirs. Marine Geodesy, 33, 204-238. http://dx.doi.org/10.1080/014904 19.2010.488983.

Chander, S., \& Ganguly, D. (2017). Development of water level estimation algorithms using SARAL/Altika dataset and validation over the Ukai reservoir, India. Journal of Applied Remote Sensing, 11, 15. http://dx.doi.org/10.1117/1.jrs.11.016012.

Costa, P. H., Pereira, E. O., \& Maillard, P. (2016). An original processing method of satellite altimetry for estimating water levels and volume fluctuations in a series of small lakes of the Pantanal wetland complex in Brazil. XXIII ISPRS Congress, 41(B8):327-34. http://dx.doi.org/10.5194/isprsarchives-XLI-B8-327-2016.

da Silva, J., Calmant, S., Seyler, F., Rotunno, O. C., Cochonneau, G., \& Mansur, W. J. (2010). Water levels in the Amazon basin derived from the ERS 2 and ENVISAT radar altimetry missions. Remote Sensing of Environment, 114, 2160-2181. http://dx.doi. org/10.1016/j.rse.2010.04.020.

de Araújo, J. C., Guntner, A., \& Bronstert, A. (2006). Loss of reservoir volume by sediment deposition and its impact on water availability in semiarid Brazil. Hydrological Sciences Journal-Journal Des Sciences Hydrologiques, 51, 157-170. http://dx.doi.org/10.1623/ hysj.51.1.157.

Gao, Q., Makhoul, E., Escorihuela, M. J., Zribi, M., Segui, P. Q., Garcia, P., \& Roca, M. (2019). Analysis of Retrackers' Performances and Water Level Retrieval over the Ebro River Basin Using Sentinel-3. Remote Sensing, 11, 25. http://dx.doi.org/10.3390/rs11060718.

Grippa, M., Rouzies, C., Biancamaria, S., Blumstein, D., Cretaux, J. F., Gal, L., Robert, E., Gosset, M., \& Kergoat, L. (2019). Potential of SWOT for Monitoring Water Volumes in Sahelian Ponds and Lakes. IEEE Journal of Selected Topics in Applied Earth Observations and Remote Sensing, 12, 2541-2549. http://dx.doi.org/10.1109/ jstars.2019.2901434.

Jarihani, A. A., Callow, J. N., Johansen, K., \& Gouweleeuw, B. (2013). Evaluation of multiple satellite altimetry data for studying inland water bodies and river floods. Journal of Hydrology (Amsterdam), 505, 78-90. http://dx.doi.org/10.1016/j.jhydrol.2013.09.010.

Jiang, L. G., Nielsen, K., Dinardo, S., Andersen, O. B., \& BauerGottwein, P. (2020). Evaluation of Sentinel-3 SRAL SAR altimetry over Chinese rivers. Remote Sensing of Environment, 237, 13. http:/ / dx.doi.org/10.1016/j.rse.2019.111546.

Jonhnsson, R. M. F., \& Kemper, K. E. (2007). Brazil: Jaguaribe Basin. In K. Kemper, W. Blomquist, \& A. Dinar (Eds.), Integrated River Basin management through decentralization. USA: The World Bank, Springer.

Kao, H. C., Kuo, C. Y., Tseng, K. H., Shum, C. K., Tseng, T. P., Jia, Y. Y., Yang, T. Y., Ali, T. A., Yi, Y., \& Hussain, D. (2019). Assessment of Cryosat-2 and SARAL/AltiKa altimetry for measuring inland water and coastal sea level variations: a case study on Tibetan Plateau lake and Taiwan Coast. Marine Geodesy, 42, 327-343. http://dx.doi.org/10.1080/01490419.2019.1623352.

Le Gac, S., Boy, F., Blumstein, D., Lasson, L., \& Picot, N. (2019). Benefits of the Open-Loop Tracking Command (OLTC): extending conventional nadir altimetry to inland waters monitoring. Advances in Space Research, http://dx.doi.org/10.1016/j.asr.2019.10.031.

Lima Neto, I. E., Wiegand, M. C., \& de Araujo, J. C. (2011). Sediment redistribution due to a dense reservoir network in a large semi-arid Brazilian basin. Hydrological Sciences Journal-journal Des Sciences Hydrologiques, 56, 319-333. http://dx.doi.org/10.108 0/02626667.2011.553616.

Maillard, P., Bercher, N., \& Calmant, S. (2015). New processing approaches on the retrieval of water levels in Envisat and SARAL radar altimetry over rivers: A case study of the Sao Francisco River, Brazil. Remote Sensing of Environment, 156, 226-241. http:// dx.doi.org/10.1016/j.rse.2014.09.027.

Michailovsky, C. I., McEnnis, S., Berry, P. A. M., Smith, R., \& BauerGottwein, P. (2012). River monitoring from satellite radar altimetry 
in the Zambezi River basin. Hydrology and Earth System Sciences, 16, 2181-2192. http://dx.doi.org/10.5194/hess-16-2181-2012.

Pail, R., Fecher, T., Barnes, D., Factor, J. F., Holmes, S. A., Gruber, T., \& Zingerle, P. (2018). Short note: the experimental geopotential model XGM2016. Journal of Geodesy, 92, 443-451.

Pereira, M. (2018). Relatório de Elaboração da CAV. ANA CAV Açudes. Relatório Técnico referente ao contrato ANA 006/2017, Lote 02 - Açude Poço da Cruz executado por meio do consórcio ARV: AEROS AT Engenharia e Aerolevantamentos Ltda. Brasil: RURAL TECH Comércio e Serviços EIRELI e VISAOGEO Ltda.

Ricko, M., Birkett, C. M., Carton, J. A., \& Cretaux, J. F. (2012). Intercomparison and validation of continental water level products derived from satellite radar altimetry. Journal of Applied Remote Sensing, 6, 23. http://dx.doi.org/10.1117/1.jrs.6.061706.

Schwatke, C., Dettmering, D., Borgens, E., \& Bosch, W. (2015). Potential of SARAL/AltiKa for Inland Water Applications. Marine Geodesy, 38, 626-643. http://dx.doi.org/10.1080/014904 19.2015.1008710.

Sulistioadi, Y. B., Tseng, K. H., Shum, C. K., Hidayat, H., Sumaryono, M., Suhardiman, A., Setiawan, F., \& Sunarso, S. (2015). Satellite radar altimetry for monitoring small rivers and lakes in Indonesia. Hydrology and Earth System Sciences, 19, 341-359. http://dx.doi. org/10.5194/hess-19-341-2015.

Toledo, C. E., de Araujo, J. C., \& de Almeida, C. L. (2014). The use of remote-sensing techniques to monitor dense reservoir networks in the Brazilian semiarid region. International Journal of Remote Sensing, 35, 3683-3699. http://dx.doi.org/10.1080/01431 161.2014.915593.

\section{Authors contributions}

Alfredo Ribeiro Neto: Conceptualization, data curation, formal analysis, funding acquisition, investigation, methodology, validation, visualization, writing-original draft.

Sajedeh Behnia: Conceptualization, data curation, formal analysis, investigation, methodology, software, writing-original draft.

Mohammad Tourian: Data curation, formal analysis, investigation, methodology, software, writing-original draft.

Fábio Araújo da Costa: Data curation, investigation, methodology, validation.

Nico Sneeuw: Formal analysis, methodology, supervision, writingoriginal draft.

Editor in-Chief: Adilson Pinheiro

Associated Editor: Fernando Mainardi Fan 